Drita Saliu-Abdulahi

University of Oslo/Maarif International Schools, R.N.Macedonia

Glenn Ole Hellekjer

University of Oslo

DOI: http://dx.doi.org/10.5617/adno.8299

\title{
Upper secondary school students' perceptions of and experiences with feedback in English writing instruction
}

\begin{abstract}
This paper presents a survey of student perceptions of feedback in English writing in a context where formative assessment is mandatory. The study comprises 329 first year upper secondary school students from seven schools in eastern Norway, and uses a survey to examine their perceptions of and experiences with feedback in EFL writing instruction. Overall, the findings reveal that students receive varied feedback, on language as well as global errors, but primarily to finished and graded texts. There is little use of feedback between drafts, or of oral conferencing and peer-feedback. While many students do not follow up feedback at all, those who do tend to focus on language error correction and less on global errors. However, student follow up in general, and of global errors in particular, increases markedly with unfinished and ungraded texts, possibly because of available time and teacher support during the revision process. This indicates that feedback utilization can be improved by setting aside classroom time to work with texts between drafts during which students can receive teacher support, and by making this an integrated part of English writing instruction.
\end{abstract}

Key words: L 2 writing instruction, feedback/formative feedback, formative assessment, multiple-sourced feedback.

\section{Elevers oppfatninger om og erfaringer med tilbakemeldinger de får i skriveundervisningen i engelskfaget i den videregående skole}

\begin{abstract}
Sammendrag
Denne artikkelen presenterer en kvantitativ studie av tilbakemeldinger i engelsk skriveundervisning i en kontekst hvor formativ vurdering er læreplanfestet. Den undersøker hvordan 329 norske VG1-studenter fra syv videregående skoler i øst Norge opplever og følger opp tilbakemeldingene de får som del av engelskfagets skriveundervisning. Funnene viser at studentene får variert feedback, med god balanse mellom kommentarene på språkfeil som på mer generelle feil med teksten, men at tilbakemeldingene først og fremst gis til ferdige tekster med karakter. Det er lite bruk av feedback til uferdige, ikke karaktervurderte tekster, av muntlig veiledning og av feedback fra andre studenter. Mens mange studenter ikke følger opp feedback
\end{abstract}


overhodet, øker oppfølgingen, av språkfeil og i enda større grad av såkalte «globale» feil, markant de relativt sjeldne gangene de får til å arbeide med uferdige, ikke karaktervurderte tekster. Dette tyder på at utnyttelsen av feedback kan bedres ved at elevene får arbeide med uferdige tekster og med lærerstøtte mens de reviderer, og dette gjøres til en integrert del av engelskundervisningen.

Nøkkelord: L2 skriving, skriveundervisning tilbakemeldinger, formativ vurdering, vurdering for læring, ulike tilbakemeldingsmodaliteter

\section{Introduction}

Formative feedback is a powerful tool in improving writing (Biber, Nekrasova, \& Horn, 2011; K. Hyland \& F. Hyland, 2006a; Sommers, 2006; Underwood \& Tregidgo, 2006), a core skill for academic advancement and therefore prioritized in school curricula. However, its effectiveness depends on a number of factors; students need to "notice", "accept", and "understand" feedback (Underwood \& Tregidgo, 2006, p. 75); they need to be involved in feedback process (Black \& Wiliam, 2006); they need to be exposed to and use different forms of feedback (Hyland \& Hyland, 2006); and, most importantly, feedback should be "actionable" (Alvarez et al. 2014, p.4). This, in turn, hinges upon its implementation, how well teachers understand and operationalize the principles of formative feedback in their classrooms and how well the students understand and engage with it.

In 2009 the Norwegian Ministry of Education made the use of Formative Assessment (hereafter FA) pedagogy (Ministry of Education, 2009) mandatory in primary and secondary education. Despite this, a number of multidisciplinary studies (Gamlem \& Munthe, 2014; Havnes, et al., 2012) indicate that current feedback practices do not necessarily comply with the current FA requirements in Norway. The same is the case for English instruction (L2), the focus of this study, where recent studies, with the partial exception of Horverak's (2015) study, indicate that feedback in English writing instruction is a problematic area (SaliuAbdulahi, Hellekjær \& Hertzberg, 2017; Saliu-Abdulahi, 2017; Burner, 2016; Horverak, 2016). For example, Saliu-Abdulahi (2017) finds that feedback is mostly given on finished and graded texts, and that students rarely get the opportunity to act on feedback while writing. Moreover, alternative forms of feedback, with the exception of self-assessment, are rarely practiced (SaliuAbdulahi, 2017; Burner, 2016; Horverak, 2015, 2016). Furthermore, these findings stand in contrast to teachers' claims that they attempt to comply with FA regulations, and that they clearly recognize the important role of feedback in the writing process (Burner, 2016; Saliu-Abdulahi, Hellekjær \& Hertzberg, 2017).

In light of these largely negative findings, it is therefore important to investigate the current implementation of FA, more specifically what kind of feedback students report receiving, when they receive it, how they understand it, 
and whether they can use the feedback. This study focuses on first year, fivelessons-per-week, compulsory English course in the college preparatory branch of Norwegian upper secondary school. Considering the above mentioned points about the role of feedback in FA pedagogy and in writing development, and the findings of small-scale qualitative studies done in Norway (Burner, 2016, SaliuAbdulahi, Hellekjær \& Hertzberg, 2017; Saliu-Abdulahi, 2017), we opted for a somewhat larger, quantitative survey of student perceptions of feedback comprising 329 first-year students from 14 classes at seven different upper secondary schools in eastern Norway. Our research questions are the following:

1. What types and forms of feedback do students report receiving on their written texts?

2. How is student engagement with feedback characterized when they receive a) feedback on texts with grades and b) feedback on texts without grades?

3. Which aspects of student engagement with written text covary positively with students' grades?

In other words, we wished to investigate whether the trend found in SaliuAbdulahi (2017), with feedback primarily on finished and graded texts, an almost exclusive reliance on the teacher feedback, and little opportunity to act on feedback combined with low student engagement with feedback, would persist in a larger sample.

\section{Literature review}

\section{Defining formative assessment and feedback}

There is an ongoing shift in education from summative to formative assessment (Lee, 2007b). Summative feedback is normally retrospective, associated with a grade, and serves to justify the assessment, whereas formative feedback is more prospective and tailored to contribute to learning (Yorke, 2003). To function formatively, formative feedback needs to be guided by three questions: Where am I? How am I doing? and Where to next? (Hattie \& Timperley, 2007; see also Black \& Wiliam, 1998, and Sadler, 1989). Furthermore, learners need to use and internalize the feedback as they progress.

The present study draws on Sadler's definition of feedback: 'The information about the gap between actual and reference level is considered as feedback only when it is used to alter the gap' (Sadler 1989, p.121, italics in original). For writing, this means applying learning to another draft, (i.e. of the text at hand) and in future writings (Lee, 2014; 2017). Furthermore, while in summative feedback the teacher dominates, the aim of formative feedback is to empower students to play an active role alongside the teacher and their peers in becoming 'selfregulated, self-monitoring, and autonomous learner[s]' (Lee, 2016, p.259). In fact, 
self-regulation together with self-efficacy are the main areas of difficulty in writing instruction (Graham \& Harris, 2000). If these reflective actions are activated, students can develop writer autonomy (Lee, 2017). To do so, however, students will require guidance from their teachers (Hawe \& Dixon, 2014).

\section{A brief overview of international studies of feedback in L2 writing instruction}

Previous studies on L2 writing have investigated various aspects of feedback in different writing contexts (e.g. Ferris, 1999, 2003; K. Hyland, 1990; F. Hyland, 1998; Sommers, 1982). Most of these, however, were conducted in universities or colleges; very few studies of feedback have been conducted in school contexts (Biber et al., 2011). Likewise, few feedback studies have been informed by FA. Among these few, Harris and colleagues have conducted relevant studies in New Zealand (Harris, Brown \& Harnett, 2014; Harris \& Brown, 2013) and Lee and her colleagues in exam-driven contexts in Asia (Lee, 2004; 2007a; Lee \& Coniam, 2013). For example, Harris et al. (2014) found that despite the strong commitment to student-centered assessment for learning in New Zealand, feedback practices were still teacher-led and dominated by grades and written comments. Lee and her colleagues, similarly, found that teachers usually give feedback on finished texts and evaluate the texts retrospectively, instead of providing formative feedback on multiple drafts and assessing prospectively (Lee, 2007a; Lee \& Coniam, 2013). They also found that, despite teachers' efforts to comply with FA principles, they failed to regularly engage students in peer-assessment and in writing multiple drafts, other important FA strategies for L2 writing development (Lee, 2017). Instead, they focused their attention to error correction (EC) and the awarding of summative grades. In fact, EC and the primacy of form have long been debated among L2 writing teachers (e.g. F. Hyland, 2003; Lee, 2004, 2007a; Truscott, 1996; Ferris, 1999), not to mention among English teachers all around the world (Furneaux, Paran, \& Fairfax, 2007; Evans, Hartshorn \& Tuioti, 2010).

\section{Studies of formative assessment and feedback in Norway}

The introduction of FA pedagogy in Norway (Ministry of Education, 2009) led to a number of projects designed to support its implementation (Burner, 2015; Ministry of Education, 2011). It also raised awareness about the role of feedback in this pedagogy and put feedback on the research agenda. The Framework for basic skills (The Norwegian Directorate of Education and Training, 2013), for example, emphasizes the role of feedback as inherent for revision and writing development. However, studies of feedback on L1 writing (Bueie, 2015, 2016; Eriksen, 2017) and in various subjects (Gamlem \& Smith, 2013; Gamlem \& Munthe, 2014; Havnes et al., 2012), show that the overall situation concerning feedback - across subjects and levels - falls short of expectations.

In English writing, the situation is similar. Although there is unanimous agreement about the importance of feedback in writing instruction (Burner, 2015; 
2016; Horverak, 2015; 2016; Saliu-Abdulahi, Hellekjær \& Hertzberg, 2017; Saliu-Abdulahi, 2017), practices and perceptions vary, and the potential of FA principles and feedback strategies are not fully exploited. For example, as in international studies such as Lee (2008; 2011), Lee and Coniam (2011), and in Saliu-Abdulahi (2017), we find that most of the feedback is delivered to a finished text with a grade. There was also little opportunity for the follow-up, for instance by working with unfinished and ungraded texts. However, this stands in partial contrast to Horverak's (2015) study from southern Norway, where almost half of the teachers involved delivered feedback on drafts and gave students a chance to revise the text before submitting for a grade.

When it comes to the use of multiple sources of feedback, not only written teacher comments but oral teacher feedback as well as peer feedback, the findings also reveal diverging attitudes and practices. For example, oral feedback is positively viewed by both students (Burner, 2015; 2016; Saliu-Abdulahi, 2017) and teachers (Saliu-Abdulahi, Hellekjær \& Hertzberg, 2017; Burner, 2015, 2016), but is still infrequently used (see Saliu-Abdulahi, Hellekjær \& Hertzberg, 2017). Furthermore, the attitudes towards peer-feedback are mixed, and several studies reveal skepticism towards it (Saliu-Abdulahi, Hellekjær \& Hertzberg, 2017; Saliu-Abdulahi, 2017; Horverak, 2015). Interestingly, the teachers in Burner's (2015) intervention study developed positive attitudes to alternative feedback sources after being involved in the FA project. Keeping in mind that the use of FA is mandated in Norwegian schools, these contradictory findings call for studies that investigate how students experience and engage with the different forms of feedback. The studies can be used to inform teacher education and training on the one hand, and writing teaching practices on the other. This leads us to the present study of students' perceptions of and experiences with feedback in L2 writing.

\section{Student perceptions of feedback}

Students' perceptions of feedback in L2 writing is an under-researched topic, especially at the secondary school level (Harris et al., 2014). While it is important that teachers know what kind of comments students consider useful and actionable (Sommers, 2006; Underwood \& Tregidgo, 2006; Hattie \& Gan, 2011), studies of student perceptions of feedback in L1 and L2 (e.g. Straub, 1997; F. Hyland, 1998, 2003; Sommers, 2006) have given conflicting results (Underwood \& Tregidgo, 2006). For example, in an L2 context, although many studies have found that students prefer comments on form (F. Hyland, 2003; Leki, 1991), a more recent study by Calhoon-Dillahunt and Forrest (2013) found that students were less concerned with EC and preferred holistic and global comments. Similarly, in Norway, an interview study with students showed that a group of students expressed a desire for more global level comments (Saliu-Abdulahi, 2017).

Yet another trend is that students are positive to feedback from multiple sources. For example, Yu and Lee (2016) reviewed studies of peer feedback in L2 
writing, concluding that it plays an important role in L2 writing development and is appreciated by students. Furthermore, a case study by Lee (2011) describes an enthusiastic teacher who decided to re-think her feedback practices for successful FA implementation. She introduced alternative feedback sources, including oral conferences and peer feedback, and students welcomed these changes. In Sweden, Berggren (2015) investigated lower secondary school EFL students and found that giving peer feedback helped students improve their own writing - they became more aware of audience and genre, and the content of their writing improved. Lundstrom and Baker (2009) found similar results. There are few studies on other forms of feedback, but they also found that engaging with the students through oral-conferencing influences students' text revisions and helps learners overcome general writing issues (Weissberg, 2006). In fact, Ferris (2014) considers the follow up of written comments with oral-conferencing as an example of best practice.

To sum up, the international as well as domestic studies reveal a gap between the principles of FA and actual feedback practices. Although there are some signs of change, FA implementation still appears to be lagging. This may be because of teacher attitudes, knowledge, and inadequate implementation (see SaliuAbdulahi, Hellekjær \& Hertzberg, 2017). In the light of the mixed findings on student perceptions of current feedback practices in Saliu-Abdulahi (2017), as well as in other studies, we therefore need to know more about students' perceptions of and experiences with the feedback they receive. This is also the aim of the present study, to investigate what types of feedback the students get, their possibilities to act on it, and their perceptions of and engagement with the feedback provided.

\section{English in the Norwegian context and latest curriculum}

In Norwegian schools, English is compulsory from grade one to the first/second year of upper-secondary school. English is widely spoken in Norwegian society, and its teaching is considered a success story (Simensen, 2010). Norwegians also score high in international English tests (Education First, 2019). Because of high proficiency levels and extensive media input, English in Norway is in transition from being a foreign language (English as a Foreign Language [EFL]) to being a second language (English as a Second Language [ESL]) (Rindal, 2015). In the present study, however, we will use second language writing (L2 writing) synonymously for both.

Norwegian upper secondary school has two branches, the three-year, college preparatory General Studies branch, and the Vocational branch where students have two years of schooling as preparation for two-year apprenticeships. For the 2016-17 school year there were 64,256 students in both branches, of these 37,358 (58\%) in the General Studies branch. While both have largely the same English syllabus and the same examinations, the Vocational students take the compulsory 
English course over two years while the General Studies students finish it in their first.

According to the recent national curriculum aims (Knowledge Promotion [KP] 2006/13), in the subject of English upper secondary school learners are expected to attain a proficiency level between B1 and B2 (CEFR, 2001), and to have developed fairly advanced writing competence. Writing is also one of five crossdisciplinary basic skills together with reading, numeracy, oracy, and digital skills, that are to be taught across the curriculum irrespective of the subject. At the end of grade 10 and after the first-year of upper secondary school, about $30 \%$ of tenth graders and a far smaller percentage of upper secondary students are selected for national, English writing examinations. Before this, all students take 'mock' examinations that are often based upon the national written examination papers, and their performance on this test contributes to their final grade.

\section{Method}

The present quantitative study uses data from a questionnaire that was distributed to 329 sixteen-year-old, first-year upper secondary school General Studies students during the spring term of the 2016-2017 school year.

The questionnaire - Questionnaire on Perceptions of Feedback Practice (see Appendix A) - was informed by a survey used in Horverak (2016) and the findings from two qualitative studies (Saliu-Abdulahi, Hellekjær \& Hertzberg, 2017; Saliu-Abdulahi, 2017). It attempts to capture students' perceptions of and engagement with feedback and comprises three sections with 12 questions with sets of sub-items, 59 items altogether. Section I elicits background information (Q1, first language, gender, grade in English writing). Section II comprises clusters of three to seven items on different aspects of feedback (Q2 to Q11b), on sources of feedback, mode of delivery, self-assessment, engagement with feedback, etc.), all using a five-point Likert scale ranging from never to always. When possible, we used sets of items tapping into the same constructs to allow the construction of additive indices to ensure the reliability of the items by avoiding the threat of unstable and imprecise measurements (Oppenheim, 1992). Finally, section III has an open-ended question where students are asked to list suggestions for good feedback practices (Q12, My writing could/would get better, if my teacher's feedback...). This last question was added to allow for possible triangulation of survey results, and to see whether students raised additional points or provided further detail.

The survey was first piloted by Saliu-Abdulahi in three classes in three different schools, first and foremost to ascertain whether there were unclear items and whether the use of English was problematical for the students. The questionnaire was revised by rewording and deleting the items that raised questions. While there were no questions or apparent comprehension problems, it cannot be excluded that the use of English might have entailed some 
communication problems, in particular with the final, open-ended question. The need to complete the survey before the examination period started precluded a more detailed, statistical analysis with revisions of the questions. Finally, although the questionnaire drew on items from previous FA studies and was discussed with a senior and a junior researcher in the same field to ensure content validity (Litwin, 1995), the present analysis has revealed the need for further improvement.

Also due to time constraints, the participating schools and classes were selected among the partner schools that cooperate with the University of Oslo with regard to accepting teacher education students for placement, all in eastern Norway, more specifically in Oslo and neighboring Akershus County. SaliuAbdulahi contacted English teachers at the schools and asked for permission. The survey itself followed a standard protocol of informing the students according to the National Committee for Research Ethics in the Social Sciences and the Humanities (NESH) guidelines. All participants were provided clearly articulated verbal consent and were given clear instructions, and all students present during the survey agreed to participate.

The resulting convenience sample comprised 329 General Studies students from fourteen available classes at seven different schools, from a total of 37358 in this branch during the 2016-17 school year. Of these, 43\% (141) were male and $57 \%$ (187) were female, exactly the same distribution as at the national level. Norwegian was the L1 of most participants (222, or $68 \%$ ), while about a third were native speakers of other languages (98, or $30 \%$ ), and only $2 \%$ (8) were native speakers of English. To be able to see how this sample compares to the reference population, an item in the questionnaire asked the students to report the grades they received for writing in English that was used for comparison with the endof-school-year final grades set by the teacher. The 329 students had an average mean grade of 4.25 ( $\mathrm{SD}=.942$ ), on a grading scale from 1 (low) to 6 (high). The corresponding end-of-school-year national grade average was 4.3. While it should be kept in mind that final grades comprise both written and oral performance while the grades for this sample are for writing only, the sample in this study should still be reasonably comparable to the reference with regard to grades.

For the statistical analyses we used the Statistical Package for Social Sciences (SPSS). We carried out an initial analysis, primarily correlation analysis (Pearson's r) and Spearman's Rho for the individual items, with writing grades (item 1.3) as a dependent variable (see overview provided in Appendix B), as well as confirmatory factor and reliability analysis (Cronbach's alpha) to see which clusters could be merged into additive indices. In our presentation of the findings we present the percentage distributions of the answers along with statistical analysis when relevant. To enhance readability the five-point scales were merged into three, rarely, sometimes and often in the tables and figure below.

Factor and reliability analysis (Cronbach's alpha), showed that only three questions, Q6, Q7, and Q8, all tapping into the respondents' engagement with 
feedback, loaded on the same latent variable and had satisfactory alpha coefficients. For Q6, "Do you evaluate and correct your own texts when writing in English?" the three items had an alpha coefficient of $\alpha=.872$. For Q7, "Do you feel you can use the feedback to improve your writing?" the five items had a relatively high $\alpha=.876$, while for Q8, "Do you understand the feedback you receive on your text?" the four items had $\alpha=.889$. The items in these questions could therefore merged into the additive indices SelfAssessment (Q6), UtilityofFeedback (Q7), and FeedbackUnderstanding (Q8), and later used in a multiple regression model.

Finally, about $90 \%$ of the students answered the open-ended question, with two-thirds of them giving substantial answers. These answers deserve a separate analysis, and only a couple of the comments are briefly presented at the end of the findings section.

\section{Results}

In the following section we start by presenting the types and forms of feedback the students report receiving on their written texts (RQ1). Next, we see whether student engagement with feedback varies between texts with grades and texts without grades (RQ2). While we focus on presenting percentage distributions reflecting the use of different types and forms of feedback, and how this differs between texts with grades and without grades, we also include some of the more salient correlations (Pearson's r) from the exploratory analysis. We then focus which aspects of student engagement correlate positively with student grades (RQ3), including an analysis of the explained variance (multiple regression analysis) with student grades.

\section{RQ1-What types and forms of feedback do students report receiving on their written texts?}

Overall, students report receiving varied feedback on their written texts, as displayed by the answers to the items comprising Q2, which tapped into the kinds of feedback the student received and are presented in Table 1. As mentioned above, in this and the following tables and Figure 1, the five-point scale has been collapsed to three categories: Never and Rarely into Rarely, Sometimes is unchanged, and Often and Always into Often. 
Table 1. Forms of feedback the students receive Q2. What kind of a feedback do you get about your writing? $N=329$

\begin{tabular}{|c|c|c|c|c|}
\hline Item & $\begin{array}{c}\text { Rarely } \\
\%\end{array}$ & $\begin{array}{l}\text { Sometimes } \\
\%\end{array}$ & $\begin{array}{c}\text { Often } \\
\%\end{array}$ & $\begin{array}{c}\text { Total } \\
\%\end{array}$ \\
\hline $\begin{array}{l}\text { 2.1 General comments about my text } \\
\text { (written in the text and/or on the electronic } \\
\text { learning platforms } \\
\text { Learning/Fronter). }\end{array}$ & 3 & 11 & 86 & 100 \\
\hline $\begin{array}{l}\text { 2.2. Specific, detailed comments about my } \\
\text { text (written in the text and/or in the } \\
\text { margins). }\end{array}$ & 11 & 22 & 67 & 100 \\
\hline $\begin{array}{l}\text { 2.3. Oral feedback (one-on-one } \\
\text { discussion) with the teacher about my text. }\end{array}$ & 39 & 38 & 23 & 100 \\
\hline $\begin{array}{l}\text { 2.4. Written feedback from my classmates } \\
\text { about my text. }\end{array}$ & 78 & 15 & 7 & 100 \\
\hline $\begin{array}{l}\text { 2.5. Oral feedback from my classmates } \\
\text { about my text. }\end{array}$ & 77 & 16 & 7 & 100 \\
\hline
\end{tabular}

As displayed, the students receive different forms of feedback, with general or specific written comments from the teacher being most frequent, with $86 \%$ and $67 \%$ answering often. Individual oral feedback from the teacher occurs less frequently, with only $23 \%$ of students saying they receive it often, $39 \%$ answering rarely and 38\% sometimes. Peer-feedback is even less frequently used, with $78 \%$ answering rarely for written and $77 \%$ rarely for oral feedback. As can be seen in Appendix B, when correlated with item 1.3 writing grades, which uses a scale from 1 = fail to $6=$ excellent, items 2.4 and 2.5 for oral and written peer feedback had significant $(p=.01)$ but low negative correlations of $r=-0.16$ and $r=-0.12$ respectively. In other words, the greater the use of these alternative forms of feedback, the lower the grades. Items 2.1 and 2.2 on teacher feedback had significant $(p=.01)$ but moderate to low positive correlations of $r=0.25$ and $r=0.20$ respectively, while for 2.3 , oral feedback from the teacher, there was no correlation.

In L2 writing it is of particular interest to know exactly what kind of mistakes and weaknesses are commented upon, first and foremost whether these focus on language errors or on the more global aspects. In Q4 we therefore included a number of items about what the comments focused on, and the answers are presented in Table 2. 
Table 2. Focus of specific feedback

Q4. What kind of mistakes and weaknesses does the specific feedback comment on? $N=329$

\begin{tabular}{lcccc}
\hline Item & $\begin{array}{c}\text { Rarely } \\
\%\end{array}$ & $\begin{array}{c}\text { Sometimes } \\
\%\end{array}$ & $\begin{array}{c}\text { Often } \\
\%\end{array}$ & $\begin{array}{c}\text { Total } \\
\%\end{array}$ \\
\hline $\begin{array}{l}\text { 4.1. I get comments on language errors, } \\
\text { such as grammar (e.g. sentence structure, } \\
\text { verb tense, concord). }\end{array}$ & 24 & 54 & 100 \\
$\begin{array}{l}\text { 4.2. I get comments on vocabulary (e.g. } \\
\text { word choices, use of advanced }\end{array}$ & & 23 & 60 & 100 \\
vocabulary, synonyms). & & & & \\
4.3. I get comments on spelling and & 30 & 31.5 & 38.5 & 100 \\
punctuation (use of comma, full stop). & & & & 100 \\
4.4. I get comments on content and ideas \\
of the text (e.g. thesis sentence, supporting \\
sentences, use of sources, etc).
\end{tabular}

The first three items in the table, items 4.1 to 4.3 , provide information about the frequency of comments on language issues, while items 4.4, 4.5 and 4.6 focus on global issues such as content, style and structure. Interestingly, the distribution shows that students feel that they roughly get the same number of comments on both local and global issues. As displayed in Appendix B, there were no significant correlations with item 1.3, writing grades, for any of these items.

To sum up, the students in the present sample report that they first and foremost receive written feedback from their teachers, with oral and peer feedback being far less frequent. With regard to the content of the feedback on mistakes and weaknesses, it was interesting to note there was a rough balance between comments focusing on language and vocabulary and those on more global aspects of the texts such as content, style and structure.

\section{RQ2. How is student engagement with feedback characterized when they receive a) feedback on texts with grades and b) feedback on texts without grades?}

To examine to what extent the students follow up on the comments received, and whether there is a difference between the follow-up of feedback between texts with grades and without grades, the survey included two sets of identical questions. The first was Q10. How do you work with feedback on a finished and 
graded text? In 11a we then asked a Yes/No question: Q11a. Are you ever expected to work with feedback (e.g. correct mistakes, revise) with a text that is not graded yet?. The 158 (48\%) respondents who chose 'Yes' were asked to continue with $Q 11 b$, which as mentioned had the same items as $Q 10$. These items are presented below:

10.1/11.1 I correct the language errors in the text (grammar, vocabulary, spelling and punctuation).

10.2/11.2 I correct only the important language errors.

10.3/11.3 I revise and rewrite the thesis sentence in each paragraph.

10.4/11.4 I revise and rewrite one paragraph.

10.5/11.5 I revise and rewrite the text changing its content, style and structure.

In Figure 1 below the answers to these identical questions, in percent, are juxtaposed for comparison.

Comparison of feedback follow up between texts with grades and texts without grades

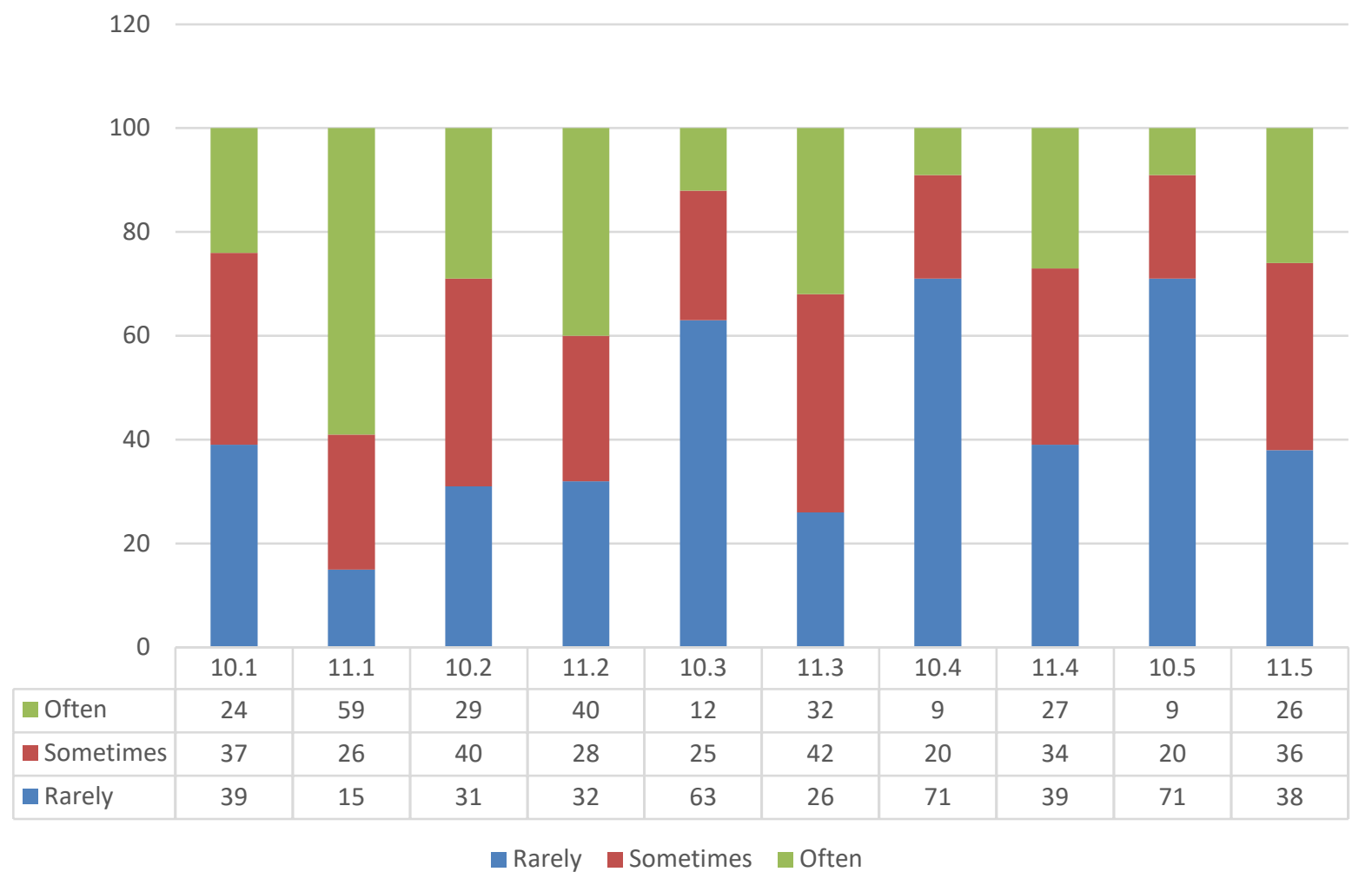

Figure 1. A comparison of follow up to texts with grades and texts without grades, with the answers (in percent) to items 10.1 to 10.5 and 11.1 to 11.5 , juxtaposed to enable comparison. $N=229 / 158$

The first trend that appears in the answers to Q10, is the many respondents who did not follow-up on the feedback they received on finished texts with grades, with percentages ranging from 39\% answering rarely for item 10.1 I correct the 
language errors in the text, to $71 \%$ for item 10.4 and $71 \%$ for 10.5 . An additional perspective on this is offered by item 10.7, I do not work with the feedback, but try to remember it in the future writings, which shows that many of those who admitted to not working with feedback ticked off for the category that they tried to remember the comments for future writing, 25\% answering sometimes and $41 \%$ answering often. The second trend was that follow up focused primarily on error correction (item 10.1 in particular), and to a far lesser extent on global issues such as sentence and paragraph revision or changing the text's style and structure (items 10.3, 10.4 and 10.5).

However, when the answers to Q10 and Q11b are compared, one can observe that follow up on language errors (11.1) increases when students work on unfinished texts without a grade. In addition, the follow up of global issues such as sentence and paragraph revision or changing the text's style and structure (see items 11.3 to 11.5) also increases. As can be seen in the answers to items 10.5 and 11.5 , the comprehensive revision of texts increases markedly, from $29 \%$ answering sometimes and often when working with finished texts with grades in 10.5 to $62 \%$ when working with unfinished texts without grades in 11.5 .

To sum up, the answers to Q10 show that many respondents do not follow up on feedback at all, although some admit to using the comments for future writings. Further, the students who do follow up tend to focus on error correction. However, the comparison to Q11b shows that for work with unfinished texts without grades, the follow up of feedback comments increases markedly, not only for language errors but for global errors as well. This points towards contextual factors, for instance that students get additional time and teacher support when working with unfinished texts without grades.

\section{RQ3. Which aspects of student engagement with written text correlate positively with student grades?}

The correlation analyses for this study are presented in Appendix B, and as can be seen, the covariations between the different items and the dependent variable student grades (item1.3), are often contradictory, with many being either fairly low, negative or not significant. One explanation might well be that many students do not follow up or save the comments for future writings, especially those who are daunted by detailed feedback. The tendency to focus on correcting language errors is another possibility.

Three questions tapped into student engagement with feedback, Q6 about the use of self-assessment when writing, Q7 on how useful they found the feedback to be (tapping into self-efficacy), and Q8, on how well they understood the feedback. The distribution and correlations for these are presented consecutively below: 


\section{Self-assessment when writing}

Three items in the survey examined self-assessment when writing. The responses indicate that the majority of respondents reported self-evaluating and correcting their texts while writing, either based on provided assessment criteria (item 6.1), on the task requirements (item 6.2), or with regard to the relevance of the content (item 6.3).

Table 3. Frequencies on student use of self-assessment

Q6. Do you evaluate and correct your own texts when writing in English? N=329

\begin{tabular}{lcccc}
\hline Item & $\begin{array}{c}\text { Rarely } \\
\%\end{array}$ & $\begin{array}{c}\text { Sometimes } \\
\%\end{array}$ & $\begin{array}{c}\text { Often } \\
\%\end{array}$ & $\begin{array}{c}\text { Total } \\
\%\end{array}$ \\
\hline $\begin{array}{l}\text { 6.1. I evaluate my text based on the } \\
\text { assessment criteria set for that text. }\end{array}$ & 23 & 35 & 42 & 100 \\
$\begin{array}{l}\text { 6.2. I evaluate my language in relation to } \\
\text { the task requirements. }\end{array}$ & 15 & 39 & 46 & 100 \\
$\begin{array}{l}\text { 6.3. I evaluate how well I include relevant } \\
\begin{array}{l}\text { content according to the requirements of } \\
\text { the task. }\end{array}\end{array}$ & 14.5 & 33 & 52.5 & 100 \\
\hline
\end{tabular}

As can be seen, the high percentages for often and sometimes clearly show that many students consistently self-evaluated and revised their own texts when writing. Since factor analysis showed that these items loaded on the same variable, and the Cronbach's Alpha for these three items was a high $\alpha=.872$, they were merged into the index SelfAssessment. When correlated (Pearson's r) with student writing grades (item 1.3), SelfAssessment had correlation of $r=0.29$ ( $p>.01$, $N=319$ ), meaning that the higher the grades, the greater use of self-assessment when writing. This might well reflect that the students with high grades have developed the strategies needed to evaluate and improve their texts while writing.

\section{Perceived usefulness of feedback}

Self-efficacy is an indicator of feedback usefulness (Zumbrunn et al., 2016). That is, if students believe that working with feedback is useful and can help them improve their writing, they will proactively engage with feedback. Question 7 comprises five items tapping into this. 
Table 4. Self-efficacy about feedback Q7. Do you feel you can use the feedback to improve your writing? $\mathrm{N}=329$

\begin{tabular}{|c|c|c|c|c|}
\hline Item & $\begin{array}{c}\text { Rarely } \\
\%\end{array}$ & $\begin{array}{l}\text { Sometimes } \\
\%\end{array}$ & $\begin{array}{c}\text { Often } \\
\%\end{array}$ & $\begin{array}{c}\text { Total } \\
\%\end{array}$ \\
\hline $\begin{array}{l}\text { 7.1. I feel I can use the feedback to } \\
\text { improve the grammar (e.g., sentence } \\
\text { structure, verb tense, concord). }\end{array}$ & 12 & 26 & 62 & 100 \\
\hline $\begin{array}{l}\text { 7.2. I feel I can use the feedback to } \\
\text { improve the vocabulary (e.g., word } \\
\text { choices, use of advanced words, } \\
\text { synonyms). }\end{array}$ & 18 & 29.5 & 52.5 & 100 \\
\hline $\begin{array}{l}\text { 7.3. I feel I can use the feedback to } \\
\text { improve the structure of my texts. }\end{array}$ & 15 & 28 & 57 & 100 \\
\hline $\begin{array}{l}\text { 7.4. I feel I can use the feedback to } \\
\text { improve the content of my texts. }\end{array}$ & 14 & 33 & 53 & 100 \\
\hline $\begin{array}{l}\text { 7.5. I feel I can use the feedback to do } \\
\text { better next time. }\end{array}$ & 8.5 & 25 & 66.5 & 100 \\
\hline
\end{tabular}

As displayed, the respondents have fairly positive views about being able to use the feedback to improve both local and global aspects of their texts, with answers ranging from $62 \%$ answering that they do so often in item 7.1, to $53 \%$ in item 7.4. However, the highest value in the table is about feeling that one can use feedback to do better next time, with $66 \%$ answering often in 7.5 .

Factorial analysis showed that the five items loaded on the same latent variable, while the Cronbach's Alpha for these three items was high, $\alpha=.876$. They could therefore be merged into an additive index, UtilityofFeedback, for which the Pearson's r correlation with student writing grades (item 1.3) was $r=$ $0.20, p=00, N=320$. In other words, the more often the students found the comments useful, and of course to the extent they had the strategies needed to follow up, the higher the writing grade.

\section{Feedback understanding}

An essential precondition for students' engagement with feedback is their understanding of the comments they get (Sadler, 2010). Question 8 had four items that tapped into this, and an overview of the distribution of the answers is provided in Table 5. 
Table 5. Students' understanding of feedback

Q. 8. Do you understand the feedback you receive on your text? $\mathrm{N}=329$

\begin{tabular}{|c|c|c|c|c|}
\hline Item & $\begin{array}{c}\text { Rarely } \\
\%\end{array}$ & $\begin{array}{l}\text { Sometimes } \\
\%\end{array}$ & $\begin{array}{c}\text { Often } \\
\%\end{array}$ & $\begin{array}{c}\text { Total } \\
\%\end{array}$ \\
\hline $\begin{array}{l}\text { 8.1. I understand teacher's general } \\
\text { comments about the text. }\end{array}$ & 5 & 9.5 & 85 & 100 \\
\hline $\begin{array}{l}\text { 8.2. I understand teacher's general } \\
\text { comments about my writing. }\end{array}$ & 4 & 13 & 88.5 & 100 \\
\hline $\begin{array}{l}\text { 8.3. I understand teacher's specific } \\
\text { comments written in the text and/or } \\
\text { margins. }\end{array}$ & 5 & 15 & 80 & 100 \\
\hline $\begin{array}{l}\text { 8.4. I understand the teacher's corrections } \\
\text { to the text. }\end{array}$ & 5.5 & 16 & 78 & 100 \\
\hline
\end{tabular}

As presented, the majority of the respondents apparently understood the comments they received, with no more than 4 to 5.5\% answering rarely. These items also correlated positively with writing grades (item 1.3). Factorial analysis showed that the items loaded on the same latent variable, and the Cronbach's Alpha for these three items was a high $\alpha=.889$. They were merged into the index FeedbackUnderstanding, for which the correlation with student writing grades (item 1.3) was $r=0.26(p=.00, N=320)$. In other words, there is a positive relation between student understanding of the feedback they receive and writing grades.

To sum up, there are clear but moderate correlations between writing grades (item 1.3) and self-evaluation when writing, the perceived utility of feedback, and between the different items on the understanding of feedback. The next question was how much of the variance in the writing grades these variables could explain, and what their unique contributions were, which could be analyzed using multiple linear regression analysis. Using the item 1.3 for student grades as dependent variable, and entering the following additive indices FeedbackUnderstanding (based on items 8.1 to 8.4), UtilityofFeedback (based on items 7.1 to 7.5), and SelfAssessment (based on items 6.1, 6.2, 6.3) as dependent variables, analysis showed that the explained variance in the grades was a fairly low $R^{2}=.125$, that is to say 12.5 percent. As presented in Figure 2, the standardized coefficients show that the highest unique contributions were from the indices SelfAssessment ( $\beta$ $=.233)$ and FeedbackUnderstanding $(\beta=.180)$. 


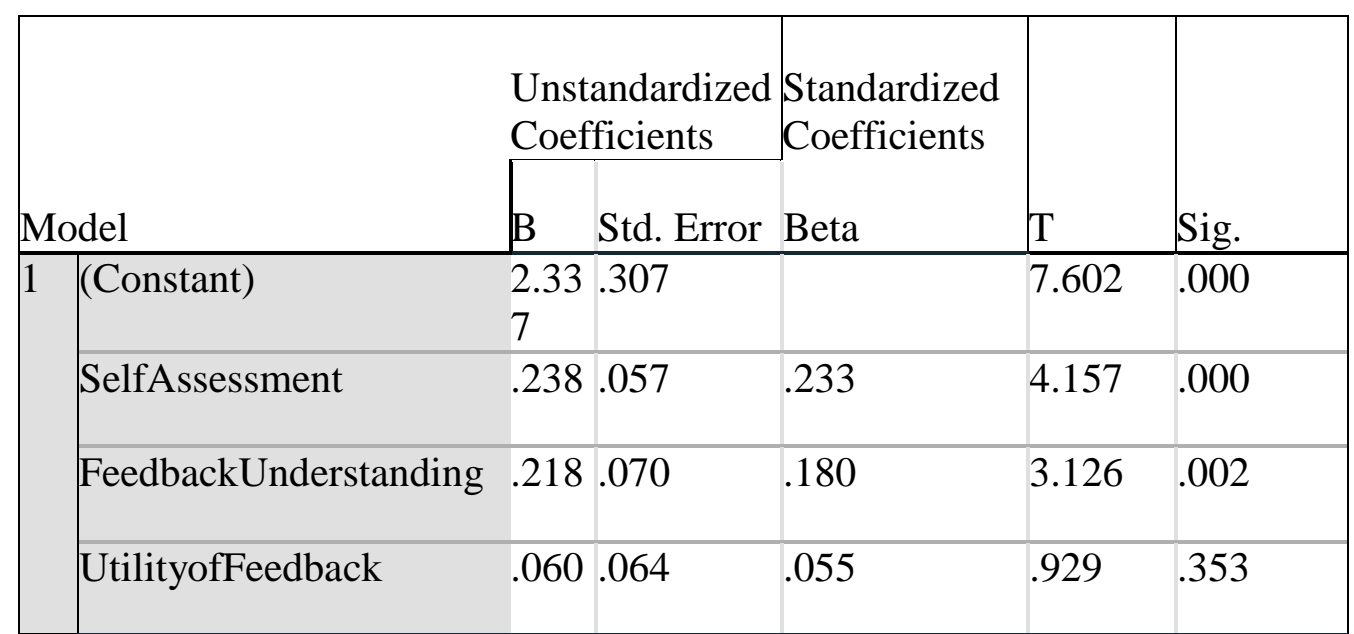

a. Dependent Variable:1.3 Grade I usually get on written work in English

Figure 2. Multiple linear regression model using student writing grades (item1.3) as dependent variable and the additive indices SelfAssessment, FeedbackUnderstanding and UtilityofFeedback that tap into different aspects of student engagement with feedback

In other words, the students who understood the feedback they received and who evaluated their texts when writing, and who were able to revise their texts accordingly, received higher grades for writing. At the same time, the low explained variance might well be due to many students not following up on the feedback they get, either because they are not able to do so, do not get the opportunity and support to do so, or because they are daunted by detailed commentary and do not follow up at all. This is in turn an indication of the need to work to enhance the students' understanding of the feedback they receive, and one means of doing so would be giving them classroom time to revise and using teacher support to scaffold the process.

\section{The open-ended question}

About two thirds of the students used the open-ended questions to comment on the feedback they received, and these comments merit a separate and more comprehensive analysis than is possible here. We have, nevertheless, included two illustrative quotes that reflects many of the student comments. One of these, which reflects the need to understand the feedback they received better, and for teacher support in doing so, was: "My writing could/would get better, if my teacher's feedback were oral and we could go through the whole text together; or [...] teacher should sit down with every student and give the feedback face-toface".

A number of the students also expressed concerns about the scope of the comments and amount of corrections they received, indirectly indicating that some might well be daunted by these. The example we have chosen is: "My writing could/would get better, if my teacher's feedback were more precise, saying exactly what I need to work on and how I should do it; or [...] gave me some examples/tasks to work on". 
In sum, these illustrative comments point to the need to help students to better understand and be able to use the feedback they receive, and second, that many are daunted by overly detailed comments, and/or are at loss about how to follow up the feedback they receive.

\section{Discussion}

The overall aim of the present study was to investigate what types of feedback first-year, upper secondary school students report receiving on their texts in English writing instruction (RQ1), their perceptions of and engagement with the feedback provided (RQ2), and which aspects of their engagement with feedback covaried positively with writing grades (RQ3).

For RQ1 the analysis showed that the students in this study received extensive feedback on the texts, first and foremost in the form of written teacher comments to finished and graded texts. Other forms of feedback, such as oral feedback from the teacher, and oral or written peer feedback, were less, or little used. As can be seen in Table 2, the specific feedback on the texts also revealed a rough balance between teacher comments on language errors, vocabulary and spelling on the one hand, and those on more global aspects of the texts, such as on content, style and structure, on the other.

RQ2 tapped into student engagement with feedback. With regard to finished texts with grades, it was clear that many students rarely followed up on the comments provided, although some mentioned that they remembered the comments for use in future writings. As can be seen in Figure 1, the students who did follow up on finished texts with grades tended to focus on correcting language errors primarily, and did little to correct the more general, global errors the teachers had commented upon. With regard to student engagement with feedback on unfinished texts without grades, only half of the sample, 158 (48\%) of the 329 respondents, mentioned having had the opportunity to do so, an indication that many teachers make little use of this approach. However, when offered the opportunity to work with unfinished texts without grades, the students' answers revealed that they made greater efforts to follow up feedback than with finished texts with grades. Further, while they worked even more with language errors, another important difference was a markedly greater focus on the following up of global issues such as content, style and structure. This implies that if one wishes students to work more extensively with global issues, and not only with language issues, it will be necessary to focus more on working with feedback on unfinished texts. It is also probable that this will offer the students the opportunity to carry out major revisions in a context where they have access to teacher support, for instance in the form of oral feedback and the opportunity to discuss the feedback they have received. Indeed, the need for this was clearly expressed in the student answers to the open questions in the questionnaire. 
RQ3 concerned how student engagement with feedback covaried with writing grades. As can be seen in Appendix B, correlation analysis often gave low and inconsistent results, except for the three questions tapping into student engagement with feedback, Q6 about the use of self-assessment when writing, Q7 on how useful they found the feedback to be (self-efficacy), and Q8 on how well they understood the feedback. After merging these into additive indices, multiple linear regression analysis using item 1.3 writing grades as dependent variable revealed a fairly low explained variance of $R^{2}=12.5$. Furthermore, as can be seen in Figure 2, it was Q6 on self-assessment when writing and Q8 student understanding that contributed most. One interpretation is that the students who understood the feedback they received, who could evaluate their texts when writing, and who were able to revise their texts accordingly, received higher grades for writing. The low explained variance of $R^{2}=12.5$, however, might also be due to many students not following up the feedback they get. This could be because they lack the knowledge to do so, and/or because they do not get the time and support they need to do so - the global comments in particular. Others might be so daunted by detailed commentary that they do not follow up on the feedback at all. An alternative, or perhaps complementary conclusion, is that the student efforts to follow up on feedback apparently give low returns, perhaps because of the clear focus on error correction and neglect of global issues. In comparison, follow up is more comprehensive when students work with comments on ungraded and unfinished texts, with more emphasis being put on global errors.

One of our most dramatic, or dispiriting finding, as displayed in Figure 1, is that many respondents do not follow-up in the feedback they receive, and the predominant focus on error correction among those who do. According to some earlier studies from the same context (Havnes et al., 2012; Burner, 2016; SaliuAbdulahi, 2017) this can at least in part be attributed to the feedback being delivered to finished texts with grades, which dominated in this study as well. However, as displayed in the comparison in Figure 1, the $48 \%$ of the students who reported having worked with feedback on unfinished texts without grades, reported a markedly higher engagement with feedback when they did so. Moreover, while they still corrected language errors, the comparison in Figure 1 shows that they in this context also paid far more attention to following up on the teachers' feedback on global issues.

To return to the limited follow up of global errors in finished and texts with grades, a number of studies explain this as the result by lack of student strategies and/or knowledge of how to move beyond sentence revision, arguing the need to teach students how to respond to feedback and how to revise beyond EC as an integral part of teaching writing (Biber et al., 2011; Calhoon-Dillahunt \& Forrest, 2013; Jonsson, 2013). We would argue that the increased focus on student followup on global errors when working with ungraded and unfinished texts points towards the importance of contextual factors, such as not overwhelming students with overly detailed feedback (Ferris, 2014). It also points towards the importance 
of providing the opportunity for classroom work on feedback with teacher support while revising. Indeed, creating a classroom context where students get the time and support to engage with feedback might well be a practical example of the FA principle of making feedback "actionable" (Alvarez et al., 2014, p.4).

However, can limited "actionability" on writing feedback in the English classrooms in this and other studies explain the low levels of student follow up? If current English writing instruction does not provide the time or the support students say they need to follow up effectively, it should not come as a surprise that many fail to do so, or only make minimal efforts. We would therefore argue that our findings indicate that adequate classroom time and teacher support, not to mention increased focus on working with unfinished texts without grades, is needed to improve engagement with feedback. In fact, we would contend that unless this is prioritized and made an integral part of English writing instruction, the long hours many teachers devote to commenting on student texts will continue giving poor returns, and the use of FA assessment, however mandatory, will remain poorly implemented.

Finally, it should be mentioned that although the findings stand in partial contrast to an earlier study (Horverak, 2015), the findings are for the most part reflected in other Norwegian and international studies. Concerning types and forms of feedback, the dominance of written teacher comments to finished and graded texts was not only found in Saliu-Abdulahi, Hellekjær and Hertzberg (2017) and in Saliu-Abdulahi (2017), but also in many other studies, national and international (Havnes et al., 2012; Jonsson, 2013; Biber et al., 2011; Harris et al., 2014; Horverak, 2016; Lee, 2017). The same was the case for the infrequent use of peer feedback and oral-conferencing, the main forms of feedback that promote active dialogic interaction. This probably reflects teacher skepticism (SaliuAbdulahi, Hellekjær \& Hertzberg, 2017; Horverak, 2015) and student negativity towards these forms of feedback (Saliu-Abdulahi, 2017). However, as shown in Burner (2015), teachers became more positive towards peer-feedback after training.

This brings us to the limitations of the present study with regard to reliability and generalizability. First, as in all surveys, the findings are self-reported and this entails limitations with regard to the reliability. Second, the social desirability bias should also be considered (Langdridge \& Hagger-Johnson, 2013). Third, although the respondents' English grades and gender distribution proved reasonably comparable to those of the reference population, the study is based on a limited, convenience sample comprising 329 respondents from 14 classes at seven schools in eastern Norway. As mentioned above, however, the findings of this study are supported by related national and international studies. We would therefore, with caution, argue that the survey provides useful information about students' perceptions of and experiences with feedback, at least in the eastern part of Norway, and that it allows the drawing of tentative conclusions with regard to pedagogical implications. 


\section{Conclusion}

The aim of this study was to expand our knowledge about upper-secondary school student perceptions of the feedback they get in English writing instruction. The findings indicate that key formative assessment (FA) principles with regard to feedback on written texts, despite their mandatory status, have not been fully implemented. We therefore argue that our findings point to the need to pay more attention to the teaching context, in particular to the need to devote classroom time and teacher support to make feedback more "actionable".

There is also a clear need for further research on-as well as discussion about-how this can be integrated into current English teaching. As part of this, a longitudinal study following students' and teachers' work throughout a semester or a year is needed to shed light what happens in the classroom with regard to feedback on a more continuous basis. Furthermore, since the findings here are self-reported, it would also be useful to investigate teachers' actual feedback and students' responses in vivo, perhaps using think-aloud protocols or video recordings. This could shed further light on facilitating factors and on the longterm utility of feedback. A larger survey comprising a representative sample of students would of course also be useful.

To conclude, we would contend that our study shows there is more to be done to enhance and exploit the formative potential of feedback in English writing instruction in Norway, as well as in other, comparable contexts. English teachers spend long hours commenting on and correcting student texts, it is high time to ensure that that their efforts yield better results.

\section{About the authors}

Dr. Drita Saliu-Abdulahi is an English teacher at Marif International School in the Republic of North Macedonia since 2018. She received a doctoral degree from the Department of Teacher Education and School Research, UiO, in February 2019. Her research interest is in the field of English writing and formative feedback.

Institutional affiliation: Marif International Schools, Republic of North Macedonia.

E-mail: dritaeee@gmail.com

Dr. Glenn Ole Hellekjær is Professor of Teaching English at the Department of Teacher Education and School Research, University of Oslo, since 2006. His research is on CLIL/EMI in secondary and tertiary education, academic reading in English, and needs analyses of English and foreign language use in business and the public sector. 
Institutional affiliation: Department of Teacher Education and School Research, University of Oslo

E-mail: g.o.hellekjar@ils.uio.no

\section{References}

Berggren, J. (2015). Learning from giving feedback: a study of secondary-level students. ELT Journal, 69(1), 58-70.

Biber, D., Nekrasova, T., \& Horn, B. (2011). The effectiveness of feedback for L1-English and L2 writing development: A meta-analysis. TOEFL iBT Re-search Report No. TOEFLiBT-14. Educational Testing Service.

Black, P., \& Wiliam, D. (1998). Assessment and classroom learning. Assessment in Education: Principles, Policy \& Practice, 5(1), 7-74.

Bueie, A. A. (2015). Summativ vurdering i formativ drakt-elevperspektiv på tilbakemelding fra heldagsprøver i norsk. [Summative assessment in formative disguise-student's perspective on written feedback in daylong- tests in Norwegian]. Acta Didactica Norge, 9(1), 1-21.

Bueie, A. A. (2016). Nyttige og mindre nyttige lærerkommentarer-slik elevene ser det. Nordic Journal of Literacy Research, 2(1), 1-28.

Burner, T. (2016). Formative assessment of writing in English as a foreign language. Scandinavian Journal of Educational Research, 60(6), 626-648.

Burner, T. (2015). Processes of change when using the portfolio to enhance formative assessment. Assessment Matters, 9(2), 52-79. http://dx.doi.org/10.18296/am.0011

Calhoon-Dillahunt, C., \& Forrest, D. (2013). Conversing in Marginal Spaces: Developmental Writers' Responses to Teacher Comments. Teaching English in the Two-Year College, 40(3), 230.

Carless, D. (2007). Learning - oriented assessment: conceptual bases and practical implications. Innovations in Education and Teaching International, 44(1), 57-66.

Council of Europe. (2001). Common European Framework of Reference for Languages: learning, teaching, assessment. Cambridge University Press.

Education First. (2019). Retrieved from https://www.ef.no/epi/regions/europe/norway/

Eriksen, H. (2017). Vurdering for læring i norskfaget: Hva kjennetegner norsklæreres skriftlige tilbakemeldinger til egne elever?. Acta Didactica Norge, 11(1), 1-26.

Evans, N. W., Hartshorn, K. J., \& Tuioti, E. A. (2010). Written corrective feedback: the practitioners’ perspective. International Journal of English Studies, 10(2), 47-77.

Ferris, D. (1999). The case for grammar correction in L2 writing classes: A response to Truscott (1996). Journal of Second Language Writing, 8(1), 1-11. 
Ferris, D. R. (2003). "Responding to Writing”, In B. Kroll (Ed.), Exploring the Dynamics of Second Language Writing (pp. 119-141). Cambridge UP.

Ferris, D. R. (2014). Responding to student writing: Teachers' philosophies and practices. Assessing Writing, 19,6-23.

Flórez, M. T., \& Sammons, P. (2013). Assessment for Learning: Effects and Impact. CfBT Education Trust. 60 Queens Road, Reading, RG1 4BS, England.

Framework for Basic Skills. (2013). The Norwegian Directorate for Education and Training. Retrieved from http://www.udir.no/ Stottemeny/English/Curriculum-inEnglish/_english/Framework-for-Basic-Skills/.

Furneaux, C., Paran, A., \& Fairfax, B. (2007). Teacher stance as reflected in feedback on student writing: An empirical study of secondary school teachers in five countries. IRAL-International Review of Applied Linguistics in Language Teaching, 45(1), 69-94.

Gamlem, S.M. \& Smith, K. (2013). Student perceptions of classroom feedback, Assessment in Education: Principles, Policy \& Practice, 20(2), 150-169.

Gamlem, S. M., \& Munthe, E. (2014). Mapping the quality of feedback to support students’ learning in lower secondary classrooms. Cambridge Journal of Education, 44(1), 7592.

Gibbs, G., \& Simpson, C. (2004). Does your assessment support your students' learning. Journal of Teaching and Learning in Higher Education, 1(1), 1-30.

Graham, S. \& Harris, K.R. (2000). The role of self-regulation and transcription skills in writing and writing development. Educational Psychologist, 35(1), 3-12.

Harris, L. R., \& Brown, G. T. L. (2013). Opportunities and obstacles to consider when using peer- and self-assessment to improve student learning: case studies into teachers' implementation. Teaching and Teacher Education, 36, 101-111.

Harris, L. R., Brown, G. T., \& Harnett, J. A. (2014). Understanding classroom feedback practices: A study of New Zealand student experiences, perceptions, and emotional responses. Educational Assessment, Evaluation and Accountability, 26(2), 107-133.

Hattie, J. \& Timperley, H. (2007). The power of feedback. Review of Educational Research, 77(1), 81-112.

Hattie, J. \& Gan, M. (2011). “Instruction Based on Feedback”, In R. E. Mayer \& P.A. Alexander (Eds), The Handbook of Research on Learning and Instruction (pp. 249271). Routledge.

Havnes, A., Smith, K., Dysthe, O. \& Ludvigsen, K. (2012). Formative assessment and feedback: Making learning visible. Studies in Educational Evaluation, 38, 21-27.

Hawe, E. M. \& Dixon, H. R. (2014). Building students' evaluative and productive expertise in the writing classroom. Assessing Writing, 19, 66-79.

Higgins, R., Hartley, P. \& Skelton, A. (2001). Getting the message across: the problem of communicating assessment feedback. Teaching in Higher Education, 6(2), 269-274. 
Horverak, M. O. (2015). Feedback practices in English in Norwegian upper secondary schools. Nordic Journal of Modern Language Methodology, 3(2),74-91.

Horverak, M. O. (2016). A survey of students' perceptions of how English writing instruction is carried out in Norwegian upper secondary schools. Journal of Second Language Teaching \& Research, 5(1), 120-144.

Huot, B. \& Perry, J. (2009), “Toward a new understanding for classroom writing assessment”, In Beard, R., Myhill, D., Jeni Riley, J. \& Nystrand, M. (Eds.), The SAGE Handbook of Writing Development. SAGE Publications, 423-435.

Hyland, K. (1990). Providing productive feedback. ELT Journal, 44(4), 279-285.

Hyland, F. (1998). The impact of teacher written feedback on individual writers. Journal of Second Language Writing, 7(3), 255-286.

Hyland, F. (2003). Focusing on form: student engagement with teacher feedback. System, 31(2), 217-230.

Hyland, K. \& Hyland, F. (2006a). Context and issues in feedback on L2 writing. In K. Hyland \& F. Hyland (Eds). Feedback in second language writing: Contexts and issues (pp. 119). Cambridge UP.

Hyland, K. \& Hyland, F. (2006b). Feedback on second language students' writing. Language Teaching, 39(2), 83-101.

Jonsson, A. (2013). Facilitating productive use of feedback in higher education. Active Learning in Higher Education, 14(1), 63-76.

Langdridge, D. \& Hagger-Johnson, G. (2013). Introduction to Research Methods and Data Analysis in Psychology. 3rd ed. Pearson.

Lee, I. (2004). Error correction in L2 secondary writing classrooms: The case of Hong Kong. Journal of Second Language Writing, 13(4), 285-312.

Lee, I. (2007a). Feedback in Hong Kong secondary writing classroom: Assessment for learning or assessment of learning?. Assessing Writing, 12, 180-198.

Lee, I. (2007b). Assessment for learning: Integrating assessment, teaching, and learning in the ESL/EFL writing classroom. Canadian Modern Language Review, 64(1), 199-213.

Lee, I. (2011). Feedback revolution: what gets in the way? ELT Journal, 65(1), 1-12.

Lee, I. (2016). Putting students at the centre of classroom L2 writing assessment. Canadian Modern Language Review, 72(2), 258-280.

Lee, I. (2017). Classroom writing assessment and feedback in L2 school contexts. Springer International Publishing.

Lee, I. \& Coniam, D. (2013). Introducing assessment for learning for EFL writing in an assessment of learning examination-driven system in Hong Kong. Journal of Second Language Writing, 22(1), 34-50. 
Leki, I. (1991). The Preferences of ESL Students for Error Correction in College-Level Writing Classes. Foreign Language Annals, 24(3), 203-218.

Lincoln, Y. S., \& Guba, E. G. (1985). Naturalistic inquiry. SAGE Publications.

Litwin, M. S. (1995). How to measure survey reliability and validity. SAGE Publications.

Lipnevich, A. A. \& Smith, J. K. (2009). “I really need feedback to learn”: students’ perspectives on the effectiveness of the differential feedback messages. Educational Assessment, Evaluation and Accountability, 21(4), 347-367.

Lundstrom, K., \& Baker, W. (2009). To give is better than to receive: The benefits of peer review to the reviewer's own writing. Journal of Second Language Writing, 18(1), 30 43.

Ministry of Education and Research (2009). Forskrift om endring i forskrift til opplæringslova [Regulation about change in the regulation of the Education Act] Downloaded from http://www.lovdata.no/ltavd1/filer/sf-20090701-0964.html.

Ministry of Education and Research (2011). Meld. St. nr. 22 (2010-2011) Motivasjon Mestring - Muligheter. Ungdomstrinnet [White Paper no. 22: Motivation - Mastering - Possibilities. Middleschool]. Oslo: Forfatteren [The author].

Ministry of Education and Research (2006/2013). Læreplaner for gjennomgående fag $i$ grunnskolen og videregående opplering [National curriculum for knowledge promotion in primary and secondary education and training]. Retrieved from http://www.udir.no/Upload/larerplaner/Fastsatte_lareplaner_for_Kunnskapsloeftet/eng lish/5/English-subject-curriculum-2013.pdf [Last accessed June, 2016]

National Directorate of Education and Training [Utdanningsdirektoratet]. (2015). Egenvurdering, elevinvolvering og involvering av lærlinger. Retrieved from https://www.udir.no/laring-og-trivsel/vurdering/underveisvurdering/involvering/

Nicol, D. J. \& Macfarlane-Dick, D. (2006). "Formative assessment and self-regulated learning: a model and seven principles of good feedback practice”, Studies in Higher Education, 31(2), 199-218.

NESH, (2005). Guidelines for Research Ethics in the Social Sciences, Law and the Humanities. National Committees for Research Ethics in Norway. http://www.etikkom.no/English/NESH/guidelines

Oppenheim, A. N. (1992). Questionnaire design, interviewing, and attitude measurement. (New ed.) Pinter.

Organisation for Economic Co-operation and Development (2011). OECD reviews on evaluation and assessment in education - Norway. OECD.

Patthey-Chavez, G. G., \& Ferris, D. R. (1997). Writing conferences and the weaving of multivoiced texts in college composition. Research in the Teaching of English, 31, 51-90.

Rindal, U. (2015). "Who owns English in Norway? L2 attitudes and choices among learners”, In A. Linn, N. Bermel \& G. Ferguson (Eds.). Attitudes towards English in Europe. English in Europe (pp. 241-270). De Gruyter Mouton. 
Roe, A. \& Helstad, K. (2014). Den andre skriveopplæringen i Norge - om prosesskriving og skriving i og på tvers av fag, In R. E. Hvistendahl \& A. Roe, (Eds.), Alle tiders norskdidaktiker. Festskrift til Frøydis Hertzberg på 70-årsdagen (Del 2: Å lære å skrive. (pp. 171 - 193). Novus Forlag. ISBN 978-82-7099-784-8.

Sadler, D.R. (1989). Formative assessment and the design of instructional systems. Instructional Science, 18, 119-144.

Sadler, D. R. (1998). Formative Assessment: revisiting the theory. Assessment in Education: Principles, Policy and Practice, 5(1), 77-84.

Sadler, D. R. (2010). Beyond feedback: Developing student capability in complex appraisal. Assessment \& Evaluation in Higher Education, 35(5), 535-550.

Saliu-Abdulahi, D., Hellekjær, G. \& Hertzberg, F. (2017). Teachers’ (formative) feedback practices in EFL writing classes in Norway. Journal of Response to Writing, 3(1), 3155.

Saliu-Abdulahi, D. (2017). Scaffolding writing development: How formative is the feedback?. Moderna Språk, 111(1), 127-155.

Shute, V. (2008). Focus on Formative Feedback. Review of Educational Research, 78(1), 153-189.

Simensen, A. M. (2010). English in Scandinavia: A success story. In Wyse, D., Andrews, R. \& Hoffman, J. (Eds.), The Routledge international handbook of English, language and literacy teaching (pp. 472-483). Routledge.

Sommers, N. (1982). Responding to student writing. College Composition and Communication, 33(2), 148-156.

Sommers, N. (2006). Across the Drafts. College Composition and Communication, 58(2), 248257.

Straub, R. (1997). Students' Reactions to Teacher Comments: An Exploratory Study. Research in the Teaching of English, 31(1), 91-119.

Topping, K. (2003). Self and peer assessment in school and university: Reliability, validity and utility. In M. Segers, F. Dochy \& E. Cascallar (Eds.), Optimising new modes of assessment: In search of qualities and standards (pp. 55-87). Springer.

Truscott, J. (1996). The case against grammar correction in L2 writing classes. Language Learning, 46, 327-369.

Underwood, J. S., \& Tregidgo, A. P. (2006). "Improving student writing through effective feedback: Best practices and recommendations.” Journal of Teaching Writing, 22(2), 73-97.

Weissberg, R. (2006). Scaffolded feedback: Tutorial conversations with advanced L2 writers. In K. Hyland \& F. Hyland (Eds.), Feedback in second language writing: Contexts and issues (pp. 246-265). Cambridge UP.

Wiliam, D. (2011). What is assessment for learning?. Studies in Educational Evaluation, 37(1), 3-14. 
Yorke, M. (2003). Formative assessment in higher education: Moves towards theory and the enhancement of pedagogic practice. Higher Education, 45(4), 477-501.

Yu, S., \& Lee, I. (2016). Exploring Chinese students' strategy use in a cooperative peer feedback writing group. System, 58, 1-11.

Zumbrunn, S., Marrs, S., \& Mewborn, C. (2016). Toward a better understanding of student perceptions of writing feedback: a mixed methods study. Reading and Writing, 29(2), 349-370. 


\section{Appendix A}

This questionnaire is included in case of peer review. The finished article will include a note that the questionnaire will be made available on request.

\section{Questionnaire on Perceptions of Feedback Practices}

This is a voluntary, anonymous survey about English writing instruction. You may decline to take part in it before, or withdraw during the survey.

In the questionnaire you are asked questions about feedback you have received in English writing lessons. The goal of this study is NOT to evaluate the teachers, but to improve feedback and the teaching of writing. The questionnaire results will be used for my doctoral project at the Department of Teacher Education and School Research, University of Oslo.

It would be appreciated if you answer as honestly as possible by choosing ONE answer for each question. It will take no more than 20 minutes. Please, do not sign your name, the survey is anonymous. If you have questions, feel free to ask me.

Thank you for taking the time to fill-in the questionnaire!

Drita Saliu-Abdulahi

\section{Section II. Answer the questions by choosing only ONE answer:}

\begin{tabular}{|c|c|c|c|c|c|c|}
\hline 2 & $\begin{array}{l}\text { What kind of a feedback do you get about your } \\
\text { writing? }\end{array}$ & $\sum^{\grave{2}}$ & 㓂 & ڤ̆ & 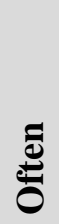 & $\frac{\substack{\pi \\
\frac{\pi}{2}}}{4}$ \\
\hline 2.1 & $\begin{array}{l}\text { General comments about my text (written in the text } \\
\text { and/or on the electronic learning platforms - ITS } \\
\text { Learning /Fronter). }\end{array}$ & & & & & \\
\hline 2.2 & $\begin{array}{l}\text { Specific and detailed comments about my text } \\
\text { (written in the text and/or in the margins. }\end{array}$ & & & & & \\
\hline 2.3 & $\begin{array}{l}\text { Oral feedback (one-on-one discussion) from the } \\
\text { teacher about my text. }\end{array}$ & & & & & \\
\hline 2.4 & Written feedback from my classmates about my text. & & & & & \\
\hline 2.5 & Oral feedback from my classmates about my text. & & & & & \\
\hline
\end{tabular}




\begin{tabular}{|c|c|c|c|c|c|c|}
\hline 3 & $\begin{array}{l}\text { What kind of comments does the general } \\
\text { feedback contain? }\end{array}$ & $\begin{array}{l}\text { ऐे } \\
\text { ż }\end{array}$ & 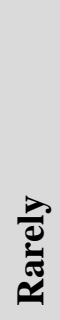 & 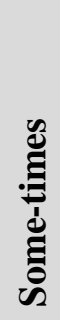 & 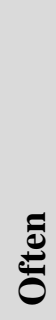 & $\frac{\substack{\mathrm{e} \\
\frac{3}{2}}}{2}$ \\
\hline 3.1 & It tells what I can do to improve my current text. & & & & & \\
\hline 3.2 & It tells what I have done badly in the text. & & & & & \\
\hline 3.3 & It tells how well I am doing in the text. & & & & & \\
\hline 3.4 & It tells how well I am doing in writing. & & & & & \\
\hline 3.5 & $\begin{array}{l}\text { It tells what I can do to improve my writing in the } \\
\text { future. }\end{array}$ & & & & & \\
\hline 3.6 & It gives explanation of the grade. & & & & & \\
\hline 4 & $\begin{array}{l}\text { What kind of mistakes and weaknesses does the } \\
\text { specific feedback comment on? }\end{array}$ & $\begin{array}{l}\text { ᄅे } \\
\text { ż }\end{array}$ & 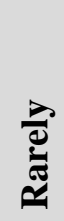 & 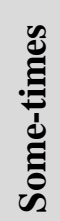 & $\stackrel{\Xi}{ٍ ٍ ̆ ~}$ & $\begin{array}{l}\stackrel{n}{\mathrm{e}} \\
\stackrel{3}{\gtrless}\end{array}$ \\
\hline 4.1 & $\begin{array}{l}\text { I get comments on language errors, such as grammar } \\
\text { (e.g., sentence structure, verb tense, concord). }\end{array}$ & & & & & \\
\hline 4.2 & $\begin{array}{l}\text { I get comments on only some important language } \\
\text { errors. }\end{array}$ & & & & & \\
\hline 4.3 & $\begin{array}{l}\text { I get comments on vocabulary (e.g., word choices, } \\
\text { use of advanced vocabulary, synonyms). }\end{array}$ & & & & & \\
\hline 4.4 & $\begin{array}{l}\text { I get comments on spelling and punctuation (use of } \\
\text { comma, full stop). }\end{array}$ & & & & & \\
\hline
\end{tabular}




\begin{tabular}{|c|c|c|c|c|c|c|}
\hline 4.5 & $\begin{array}{l}\text { I get comments on content and ideas of the text (e.g., } \\
\text { thesis sentence, supporting sentences, use of sources, } \\
\text { etc). }\end{array}$ & & & & & \\
\hline 4.6 & $\begin{array}{l}\text { I get comments on the writing style (e.g., formal or } \\
\text { informal language). }\end{array}$ & & & & & \\
\hline 4.7 & $\begin{array}{l}\text { I get comments on how I structure and organize the } \\
\text { text. }\end{array}$ & & & & & \\
\hline 5 & What do you do after you receive the feedback? & $\sum_{\grave{z}}^{\grave{z}}$ & $\frac{\lambda}{d !}$ & 岂 & $\underbrace{ \pm}_{0}$ & 尝 \\
\hline 5.1 & $\begin{array}{l}\text { I read carefully the comments in the end of the text } \\
\text { and/or ITS Learning/Fronter to understand my } \\
\text { strengths and weaknesses. }\end{array}$ & & & & & \\
\hline 5.2 & $\begin{array}{l}\text { I read carefully the comments in the text and/or } \\
\text { margins to understand my mistakes. }\end{array}$ & & & & & \\
\hline 5.3 & $\begin{array}{l}\text { I read the comments to understand the grade I get } \\
\text { (and ignore the rest). }\end{array}$ & & & & & \\
\hline 5.4 & $\begin{array}{l}\text { I do not read the feedback comments, I only look at } \\
\text { the grade. }\end{array}$ & & & & & \\
\hline 5.5 & $\begin{array}{l}\text { I save the feedback comments and look at them for } \\
\text { future writing. }\end{array}$ & & & & & \\
\hline 5.6 & $\begin{array}{l}\text { I ignore the teacher's comments when I do not } \\
\text { understand them. }\end{array}$ & & & & & \\
\hline 5.7 & $\begin{array}{l}\text { I ask the teacher when I do not understand the } \\
\text { feedback. }\end{array}$ & & & & & \\
\hline
\end{tabular}




\begin{tabular}{|c|c|c|c|c|c|c|}
\hline 6 & $\begin{array}{l}\text { Do you evaluate and correct your own texts when } \\
\text { writing in English? }\end{array}$ & ¿ & 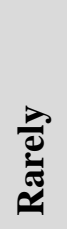 & 岂 & $\underbrace{ \pm}_{0}$ & $\frac{\infty}{\overbrace{3}^{\pi}}$ \\
\hline 6.1 & $\begin{array}{l}\text { I evaluate my text in relation to assessment criteria } \\
\text { set for that text. }\end{array}$ & & & & & \\
\hline 6.2 & $\begin{array}{l}\text { I evaluate my language in relation to the task } \\
\text { requirements. }\end{array}$ & & & & & \\
\hline 6.3 & $\begin{array}{l}\text { I evaluate how well I include relevant content } \\
\text { according to the requirements of the task. }\end{array}$ & & & & & \\
\hline 7 & $\begin{array}{l}\text { Do you feel you can use the feedback to improve } \\
\text { your writing? }\end{array}$ & ל⿺辶一 & 党 & ڤัٌ & 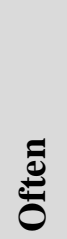 & $\frac{\infty}{3}$ \\
\hline 7.1 & $\begin{array}{l}\text { I feel I can use the feedback to improve the grammar } \\
\text { (e.g., sentence structure, verb tense, concord). }\end{array}$ & & & & & \\
\hline 7.2 & $\begin{array}{l}\text { I feel I can use the feedback to improve the } \\
\text { vocabulary (e.g., word choices, use of advanced } \\
\text { words, synonyms). }\end{array}$ & & & & & \\
\hline 7.3 & $\begin{array}{l}\text { I feel I can use the feedback to improve the structure } \\
\text { of my texts. }\end{array}$ & & & & & \\
\hline 7.4 & $\begin{array}{l}\text { I feel I can use the feedback to improve the content } \\
\text { of my texts. }\end{array}$ & & & & & \\
\hline 7.5 & I feel I can use the feedback to do better next time. & & & & & \\
\hline 8 & $\begin{array}{l}\text { Do you understand the feedback you receive on } \\
\text { your text? }\end{array}$ & ¿্̀ & 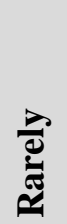 & ڤ્ٌ & 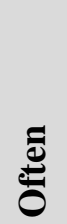 & $\overbrace{\frac{\pi}{3}}^{\infty}$ \\
\hline 8.1 & $\begin{array}{l}\text { I understand teacher's general comments about the } \\
\text { text. }\end{array}$ & & & & & \\
\hline
\end{tabular}




\begin{tabular}{|c|c|c|c|c|c|c|}
\hline 8.2 & $\begin{array}{l}\text { I understand teacher's general comments about my } \\
\text { writing. }\end{array}$ & & & & & \\
\hline 8.3 & $\begin{array}{l}\text { I understand teacher's specific comments written in } \\
\text { the text and/or margins. }\end{array}$ & & & & & \\
\hline 8.4 & I understand the teacher's corrections to the text. & & & & & \\
\hline 9 & When do you get feedback to your text? & Zे & 党 & 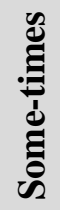 & 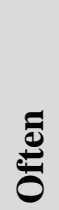 & $\frac{n}{2}$ \\
\hline 9.1 & When the text is finished and graded. & & & & & \\
\hline 9.2 & $\begin{array}{l}\text { During the writing process before the text is } \\
\text { submitted for grading. }\end{array}$ & & & & & \\
\hline 9.3 & I do not get feedback, I only get a grade. & & & & & \\
\hline 10 & $\begin{array}{l}\text { How do you work with feedback if the text is } \\
\text { finished and graded? }\end{array}$ & 己े & 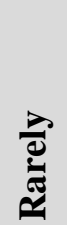 & 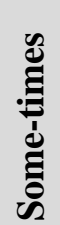 & 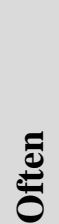 & $\sum_{\substack{2 \\
\frac{\pi}{2}}}^{\infty}$ \\
\hline 10.1 & $\begin{array}{l}\text { I correct the language errors in the text (grammar, } \\
\text { vocabulary, spelling and punctuation). }\end{array}$ & & & & & \\
\hline 10.2 & $\begin{array}{l}\text { I correct only the important language errors (e.g., in } \\
\text { some sentences) }{ }^{1} \text {. }\end{array}$ & & & & & \\
\hline 10.3 & $\begin{array}{l}\text { I revise and rewrite the thesis sentence in each } \\
\text { paragraph. }\end{array}$ & & & & & \\
\hline
\end{tabular}




\begin{tabular}{|l|l|l|l|l|l|l|}
\hline 10.4 & I revise and rewrite one paragraph. & & & & \\
\hline 10.5 & $\begin{array}{l}\text { I revise and rewrite the text changing its content, } \\
\text { style and structure. }\end{array}$ & & & & & \\
\hline 10.6 & I do not work with the feedback. UNCLEAR & & & & & \\
\hline 10.7 & $\begin{array}{l}\text { I do not work with the feedback, but try to remember } \\
\text { it in the future writings. }\end{array}$ & & & & & \\
\hline
\end{tabular}

11. a. Are you ever expected to work with feedback (e.g. correct the mistakes, revise) with a text that is NOT graded yet?
Yes
No

If your answer is NO for 11.a., skip question 11.b and move to question 12.

\begin{tabular}{|c|c|c|c|c|c|c|}
\hline 11.b & $\begin{array}{l}\text { How do you work with feedback if you are } \\
\text { working with a text that is NOT graded yet? }\end{array}$ & ¿ & 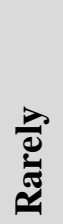 & 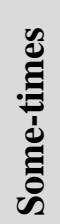 & 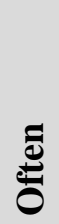 & $\frac{\infty}{2}$ \\
\hline 11.1 & $\begin{array}{l}\text { I correct the language errors in the text (grammar, } \\
\text { vocabulary, spelling and punctuation). }\end{array}$ & & & & & \\
\hline 11.2 & I correct only the important language errors ${ }^{2}$. & & & & & \\
\hline 11.3 & $\begin{array}{l}\text { I revise and rewrite the thesis sentence in each } \\
\text { paragraph. }\end{array}$ & & & & & \\
\hline 11.4 & I revise and rewrite one paragraph. & & & & & \\
\hline 11.5 & $\begin{array}{l}\text { I revise and rewrite the text changing its content, } \\
\text { style and structure. }\end{array}$ & & & & & \\
\hline
\end{tabular}




\begin{tabular}{|l|l|l|l|l|l|l|}
\hline 11.6 & I do not work with the feedback. & & & & & \\
\hline
\end{tabular}

\section{Section III. 12. Open ended question:}

Please, complete the following sentence by listing different suggestions for how you think good feedback on written text should be:

"My writing could/would get better, if my teacher's feedback ...."

${ }^{1}$ Item not analysed.

2 Item not analysed.

\section{Appendix B}

Table with overview of Person's and Spearman correlations, mean scores, standard deviations and sample numbers for Q2, Q3, Q5, Q6, Q7, Q8 , Q9, Q10, and Q11b.

\begin{tabular}{|c|c|c|c|c|c|}
\hline $\begin{array}{l}\text { Dependent variable, item 1.3. Grade I usually get on } \\
\text { written work in English. 1(fail) to } 6 \text { (high) }\end{array}$ & $\begin{array}{l}\text { Correlations } \\
\text { Pearson's r }\end{array}$ & $\begin{array}{l}\text { Correlations } \\
\text { Spearman }\end{array}$ & $\mathrm{M}$ & SD & $\mathrm{N}$ \\
\hline $\begin{array}{l}2.1 \text { General comments about my text (written in the text } \\
\text { and/or on the electronic learning platforms - ITS Learning } \\
\text { /Fronter). }\end{array}$ & $.25^{* *}$ & .25 & 4.30 & .85 & 325 \\
\hline $\begin{array}{l}\text { 2.2. Specific, detailed comments about my text (written in } \\
\text { the text and/or in the margins). }\end{array}$ & $.20 * *$ & $.18^{* *}$ & 3.85 & .99 & 327 \\
\hline $\begin{array}{l}\text { 2.3. Oral feedback (one-on-one discussion) with the } \\
\text { teacher about my text. }\end{array}$ & .00 & .02 & 2.78 & 1.02 & 326 \\
\hline 2.4. Written feedback from my classmates about my text. & $-.16^{* *}$ & -.07 & 1.91 & .98 & 325 \\
\hline 2.5. Oral feedback from my classmates about my text. & $-.12 *$ & -.07 & 1.90 & .94 & 324 \\
\hline 3.1. It tells what I can do to improve my current text. & $.17 * *$ & $.16^{* *}$ & 4.06 & .94 & 326 \\
\hline 3.2. It tells what I have done badly in the text. & -.004 & .00 & 3.98 & 1.04 & 326 \\
\hline 3.3. It tells how well I am doing in the text. & $.21^{* *}$ & $.25 * *$ & 3.80 & 1.02 & 327 \\
\hline 3.4. It tells how well I am doing in writing & $.17 * *$ & $.19 * *$ & 3.69 & .97 & 327 \\
\hline $\begin{array}{l}\text { 3.5. It tells what I can do to improve my writing in the } \\
\text { future. }\end{array}$ & $.13^{*}$ & $.16^{* *}$ & 3.84 & 1.09 & 327 \\
\hline 3.6 It gives explanation of the grade. & $.16^{* *}$ & $.17 * *$ & 3.46 & 1.13 & 327 \\
\hline $\begin{array}{l}5.1 \text { I read carefully the comments in the end of the text } \\
\text { and/or ITS Learning/Fronter to understand my strengths } \\
\text { and weaknesses. }\end{array}$ & $.22 * *$ & $.19 * *$ & 3.96 & 1.07 & 322 \\
\hline $\begin{array}{l}5.2 \text { I read carefully the comments in the text and/or } \\
\text { margins to understand my mistakes. }\end{array}$ & $.25 * *$ & $.22 * *$ & 3.95 & .98 & 324 \\
\hline $\begin{array}{l}5.3 \text { I read the comments to understand the grade I get (and } \\
\text { ignore the rest). }\end{array}$ & $-.21 * *$ & $-.21 * *$ & 2.90 & 1.19 & 323 \\
\hline $\begin{array}{l}5.4 \text { I do not read the feedback comments, I only look at the } \\
\text { grade. }\end{array}$ & $-.19 * *$ & $-.18 * *$ & 1.85 & 1.03 & 323 \\
\hline
\end{tabular}




\begin{tabular}{|c|c|c|c|c|c|}
\hline $\begin{array}{l}5.5 \text { I save the feedback comments and look at them for } \\
\text { future writing. }\end{array}$ & $.22 * *$ & $.22 * *$ & 3.17 & 1.24 & 323 \\
\hline $\begin{array}{l}5.6 \text { I ignore the teacher’s comments when I do not } \\
\text { understand them. }\end{array}$ & $-.22 * *$ & $-.16 * *$ & 1.97 & 1.07 & 323 \\
\hline $\begin{array}{l}5.7 \text { I ask the teacher when I do not understand the } \\
\text { feedback. }\end{array}$ & $.19 * *$ & $-.17 * *$ & 3.56 & 1.24 & 325 \\
\hline $\begin{array}{l}\text { 6.1. I evaluate my text based on the assessment criteria set } \\
\text { for that text. }\end{array}$ & $.24 * *$ & $.25 * *$ & 3.23 & 1.06 & 322 \\
\hline $\begin{array}{l}6.2 . \text { I evaluate my language in relation to the task } \\
\text { requirements. }\end{array}$ & $.23 * *$ & $.24 * *$ & 3.37 & .98 & 324 \\
\hline $\begin{array}{l}\text { 6.3. I evaluate how well I include relevant content } \\
\text { according to the requirements of the task. }\end{array}$ & $.29 * *$ & $.29 * *$ & 3.50 & 1.05 & 321 \\
\hline $\begin{array}{l}\text { 7.1. I feel I can use the feedback to improve the grammar } \\
\text { (e.g., sentence structure, verb tense, concord). }\end{array}$ & $.12^{*}$ & $.13^{* *}$ & 3.72 & 1.04 & 326 \\
\hline $\begin{array}{l}\text { 7.2. I feel I can use the feedback to improve the } \\
\text { vocabulary (e.g., word choices, use of advanced words, } \\
\text { synonyms). }\end{array}$ & $.15^{* *}$ & $.17 * *$ & 3.51 & 1.11 & 325 \\
\hline $\begin{array}{l}\text { 7.3. I feel I can use the feedback to improve the structure } \\
\text { of my texts. }\end{array}$ & $.17^{* *}$ & $.17 * *$ & 3.63 & 1.04 & 325 \\
\hline $\begin{array}{l}\text { 7.4. I feel I can use the feedback to improve the content of } \\
\text { my texts. }\end{array}$ & $.12^{*}$ & $.13 *$ & 3.53 & 1.01 & 325 \\
\hline 7.5. I feel I can use the feedback to do better next time. & $.25 * *$ & $.24 * *$ & 3.88 & .99 & 324 \\
\hline $\begin{array}{l}\text { 8.1. I understand teacher's general comments about the } \\
\text { text. }\end{array}$ & $.30 * *$ & $.26 * *$ & 4.25 & .88 & 326 \\
\hline $\begin{array}{l}\text { 8.2. I understand teacher's general comments about my } \\
\text { writing. }\end{array}$ & $.22 * *$ & $.17 * *$ & 4.24 & .84 & 325 \\
\hline $\begin{array}{l}\text { 8.3. I understand teacher's specific comments written in } \\
\text { the text and/or margins. }\end{array}$ & $.17^{* *}$ & $.14^{*}$ & 4.10 & .83 & 324 \\
\hline 8.4. I understand the teacher's corrections to the text. & $.17 * *$ & $.13 *$ & 4.06 & .91 & 323 \\
\hline 9.1 When the text is finished and graded. & $.27^{* *}$ & $.23^{* *}$ & 4.56 & .76 & 324 \\
\hline $\begin{array}{l}9.2 \text { During the writing process before the text is submitted } \\
\text { for grading. }\end{array}$ & -.10 & -.59 & 2.26 & 1.0 & 323 \\
\hline 9.3 I do not get feedback, I only get a grade. & $-.27 * *$ & $-.21 * *$ & 1.51 & .85 & 323 \\
\hline $\begin{array}{l}10.1 \text { I correct the language errors in the text (grammar, } \\
\text { vocabulary, spelling, and punctuation). }\end{array}$ & .12 & .13 & 2.80 & 1.07 & 326 \\
\hline $\begin{array}{l}10.2 \text { I correct only the important language errors (e.g., in } \\
\text { some sentences) }{ }^{2} \text {. }\end{array}$ & -.18 & .04 & 2.93 & 1.04 & 324 \\
\hline $\begin{array}{l}10.3 \text { I revise and rewrite the thesis sentence in each } \\
\text { paragraph. }\end{array}$ & $-.14^{*}$ & $-.13^{*}$ & 2.22 & .95 & 325 \\
\hline 10.4 I revise and rewrite one paragraph. & $-.10 * *$ & -.07 & 2.13 & .96 & 325 \\
\hline $\begin{array}{l}10.5 \text { I revise and rewrite the text changing its content, style } \\
\text { and structure. }\end{array}$ & $-.17 * *$ & $-.15^{* *}$ & 2.13 & .96 & 325 \\
\hline 10.6 I do not work with the feedback. UNCLEAR & $.12 *$ & .10 & $Z .43$ & 1.14 & 325 \\
\hline $\begin{array}{l}10.7 \text { I do not work with the feedback, but try to remember } \\
\text { it in the future writings. }\end{array}$ & .02 & .03 & 3.10 & 1.29 & 325 \\
\hline $\begin{array}{l}\text { 11.1b I correct the language errors in the text (grammar, } \\
\text { vocabulary, spelling and punctuation). }\end{array}$ & $.21 *$ & $.19 *$ & 3.73 & 1.05 & 156 \\
\hline 11.2b I correct only the important language errors ${ }^{2}$. & -.03 & -.20 & 3.11 & 1.20 & 156 \\
\hline $\begin{array}{l}\text { 11.3b I revise and rewrite the thesis sentence in each } \\
\text { paragraph. }\end{array}$ & .05 & .07 & 3.07 & 1.09 & 156 \\
\hline 11.4b I revise and rewrite one paragraph. & .06 & .10 & 2.92 & 1.09 & 154 \\
\hline $\begin{array}{l}\text { 11.5b I revise and rewrite the text changing its content, } \\
\text { style and structure. }\end{array}$ & 0.4 & .04 & 2.83 & 1.15 & 155 \\
\hline 11.6b I do not work with the feedback. & $-.30 * *$ & $-.26 * *$ & 1.82 & $1-01$ & 156 \\
\hline
\end{tabular}

